ACS Chem Biol. 2016 November 18; 11(11): 2991-2995. doi:10.1021/acschembio.6b00630.

\title{
Rational Design of Dual Agonist-Antibody Fusions as Long- acting Therapeutic Hormones
}

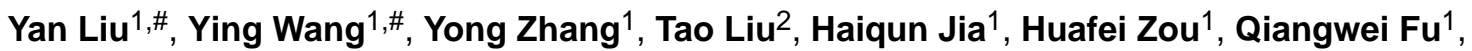 \\ Yuhan Zhang ${ }^{1}$, Lucy Lu ${ }^{1}$, Elizabeth Chao ${ }^{1}$, Holly Parker ${ }^{1}$, Van Nguyen-Tran ${ }^{1}$, Weijun Shen ${ }^{1}$, \\ Danling Wang ${ }^{1}$, Peter G. Schultz ${ }^{1,2,}$, and Feng Wang ${ }^{1,{ }^{*}}$ \\ ${ }^{1}$ California Institute for Biomedical Research, La Jolla, CA, 92037, USA \\ 2Department of Chemistry, The Scripps Research Institute, La Jolla, CA, 92037, USA
}

\section{Abstract}

\begin{abstract}
Recent studies have suggested that modulation of two or more signaling pathways can achieve substantial weight loss and glycemic stability. We have developed an approach to the generation of bi-functional antibody agonists that activate leptin receptor and GLP-1 receptor. Leptin was fused into the complementarity determining region 3 loop of the light chain alone, or in combination with exendin-4 (EX4) fused at the N-terminus of the heavy chain of Herceptin. The antibody fusions exhibit similar or increased in vitro activities on their cognate receptors, but 50 100 folder longer circulating half-lives in rodents compared to the corresponding native peptides/proteins. The efficacy of the leptin/EX4 dual antibody fusion on weight loss, especially fat mass loss, was enhanced in $o b / o b$ mice and $D I O$ mice compared to the antibody fusion of either EX4 or leptin alone. This work demonstrates the versatility of this combinatorial fusion strategy for generating dual antibody agonists with long half-lives.
\end{abstract}

Body weight and glucose homeostasis are regulated by complex peptide hormones that control peripheral and central metabolic signaling pathways. Leptin ${ }^{1,2}$ is a key regulator of energy metabolism due to its ability to reduce body weight by inhibiting food intake and increasing energy expenditure ${ }^{3,4}$. Leptin is also able to activate the insulin receptor substrate (IRS)/phosphatidylinositide 3-kinase (PI3K) pathway which is essential for the regulation of glucose homeostasis ${ }^{5}$. However, attempts to normalize body weight and glycaemia with leptin have been disappointing ${ }^{6,7}$. Leptin reduces body weight in obese congenitally leptin-deficient rodents and humans ${ }^{8-10}$, but failed to do so in diet-induced obesity due to leptin resistance ${ }^{11-14}$. Emerging evidence from preclinical studies supports the concept that targeting two or more signaling pathways might be necessary to effectively achieve substantial weight loss and glycemic stability. Co-administration of leptin along with additional hormones, including amylin, cholecystokinin (CCK), FGF21, or GLP-1 analogs, resulted in increased leptin sensitivity and led to decreased body weight in rodents

\footnotetext{
*Correspondence: fwang@ calibr.org (F. W.) and schultz@scripps.edu (P.G.S.).

${ }^{\text {\#Contributed equally }}$

Supporting Information Available: This material is available free of charge via the Internet.
} 
and humans ${ }^{3}$. This observation suggests that reversing leptin resistance under DIO conditions with combinatorial therapies is one possible approach to the treatment of obesity.

Previously, we fused human leptin into the complementarity determining region (CDR) 3 loop of Herceptin (a humanized anti-Her2 antibody) light chain (CDR3L) to generate a Herceptin-leptin fusion protein to improve the pharmacokinetic properties of leptin by exploiting the long circulating half-life of the antibody scaffold ${ }^{15}$. We also generated bifunctional antibody chimeras by simultaneous fusion of two cytokines into CDR3H and CDR3L with excellent physicochemical properties and comparable in vitro activities relative to the native proteins ${ }^{15-17}$. Here we have combined these two previous approaches to generate long-acting bi-functional antibodies by fusion of EX4 to the N-terminus of the heavy chain and leptin into the CDR3L loop of Herceptin. The dual antibody agonist retained the in vitro activities of the parent polypeptides on the cognate receptors, but had significantly increased serum half-life. Herceptin-EX4-Leptin (Her-EX4-Lep) showed an enhanced effect on body weight loss, especially fat mass loss compared to the leptinantibody fusion alone in both $o b / o b$ and $D I O$ mouse models.

EX4 flanked with a flexible linker or rigid helical linker, was fused to the N-terminus of the heavy chain and human leptin was fused into the CDR3L loop of Herceptin (Her) via a coiled-coil linker. Herceptin is a humanized anti-Her2 receptor monoclonal antibody used clinically for the treatment of breast cancer ${ }^{18-21}$. Herceptin has excellent physiochemical and pharmacological properties and low immunogenicity, and therefore is an ideal carrier scaffold to generate antibody fusions. The heavy and light chain fusion proteins were coexpressed to generate the dual antibody agonist Her-EX4-Lep. Alternatively, the heavy or light chain fusion protein was paried with the corresponding wildtype light or heavy chain to generate the single antibody agonists, Her-EX4 and Her-Lep . The hIgG1 constant regions of all fusion antibodies were modified with seven mutations (E233P, L234V, L235A, $\Delta$ G236, A327G, A330S, and P331S) to reduce complement-dependent and antibody dependent cellmediated cytotoxicity 22,23 (Figure 1). A single mutation N82K was introduced into leptin ${ }^{24}$ to afford a leptin null-function mutant (Her-EX4-Lep ${ }^{\mathrm{M}}$ ) as a control for the HerEX4-Lep dual fusion with similar GLP-1 receptor (GLP-1R) activity. The fusion proteins were expressed in Free-Style HEK293 cells by transient transfection, purified using protein A chromotography and analyzed by SDS-PAGE (Figure S1). After treatment with peptide$\mathrm{N}$-glycosidase and DTT, mass spectral analysis indicated that the masses of the heavy and light chains of the purified dual agonist fusion proteins matched the calculated molecular weights (Table S1). All fusion proteins can be concentrated to over $10 \mathrm{mg} / \mathrm{mL}$ in PBS (pH 7.4) without aggregation as determined by size-exclusion chromatography, and showed no loss of stability or activity after long term storage at $-20{ }^{\circ} \mathrm{C}$.

The in vitro activities of the dual and single antibody fusions were measured in cell-based assays. GLP-1R activation was determined using HEK293 cells overexpressing GLP-1R and carrying a cAMP response element (CRE)-luciferase (Luc) reporter. To determine the in vitro activities of the leptin fusion proteins, a leptin-dependent cell proliferation assay was carried out using a murine $\mathrm{Ba} / \mathrm{F} 3$ cell line with stable expression of human leptin receptor. The antibody fusions of EX4, leptin and the Her-EX4-Lep all have higher biological activities than the parent EX4 (1.8 9.8 fold) and leptin (1.2 1.5 fold) polypeptides which 
may be due to avidity. There is some activity loss in the dual antibody fusion relative to the mono-fusions which could be to unfavorable interactions of the noncognate polypeptide with receptor binding (Table 1). Flow cytometry analysis also showed that dual fusion at the $\mathrm{N}$ terminus and CDR3L loop of Herceptin significantly (> 50 fold) reduced Her2 binding by the original Herceptin antibody scaffold (Figure S2), which demonstrates that Herceptin is a suitable scaffold for generation of antibody CDR fusions. From this perspective, therapeutic antibodies that do not target human proteins are more favorable as antibody scaffolds. Indeed, we have recently demonstrated that Synagis (Pavilizumab), an FDA approved RSV neutralizing antibody, could be used as a scaffold to generate CDR loop or terminal protein fusions 25 .

We next determined the circulating half-life of the dual-agonist fusion protein Her-EX4-Lep in rats. Plasma samples were collected from day 0 to day 7 and analyzed by a standard sandwich ELISA using an anti-human Fc antibody and an EX4- or leptin-specific antibody. The estimated terminal half-lives $\left(\mathrm{t}_{1 / 2}\right)$ for subcutaneous injection are $47 \mathrm{hrs}$ based on EX4 detection and $18 \mathrm{hrs}$ based on leptin detection (Figure 2, Table $\mathrm{S} 2$ ). The clearance $\left(\mathrm{C}_{\mathrm{L}}\right)$ for intravenous injection is $0.16 \mathrm{ml} / \mathrm{hr}\left(2.67 \times 10^{-3} \mathrm{ml} / \mathrm{min}\right)$ based on EX4 detection and 0.19 $\mathrm{ml} / \mathrm{hr}\left(3.17 \times 10^{-3} \mathrm{ml} / \mathrm{min}\right.$ or $\left.2.54 \times 10^{-2} \mathrm{ml} / \mathrm{min} / \mathrm{kg}\right)$ based on leptin detection. Compared to the rapid plasma clearance of EX4 $\left(\mathrm{t}_{1 / 2}<0.5 \mathrm{hr}{ }^{26}\right.$ and $\left.\mathrm{C}_{\mathrm{L}}=3.62 \mathrm{ml} / \mathrm{min}^{27}\right)$ and leptin $\left(\mathrm{t}_{1 / 2}\right.$ 5-7 $\min ^{27}$ and $\mathrm{C}_{\mathrm{L}}=6.16 \mathrm{ml} / \mathrm{min} / \mathrm{kg}^{28}$ ) in rats, Her-EX4-Lep exhibited a slower absorption phase, greater $\mathrm{C}_{\max }$ and much slower plasma clearance. The distinct half-lives of EX4 and leptin moieties suggest that the degradation rates of the EX4 and leptin moieties are quite different. This could lead to different duration of action on GLP-1R and ObR in vivo after dosing of the dual-fusion molecule, and may require optimization to achieve maximal efficacy.

The in vivo activity of Her-EX4-Lep was first evaluated in a leptin-sensitive $o b / o b$ mouse model. For comparison, Her-EX4, Her-Lep, Her-EX4-Lep ${ }^{\mathrm{M}}$ and the combination of Her-Lep and Her-EX4-Lep ${ }^{\mathrm{M}}$ were subcutaneously injected at the same dosage $(5 \mathrm{mg} / \mathrm{kg})$ and frequency (every other day). Compared to the vehicle (saline) group, the mice dosed with Her-EX4-Lep, Her-Lep, and Her-Lep/Her-EX4-Lep ${ }^{\mathrm{M}}$ showed significant and continuous body weight loss during the 9 day treatment period. The dual agonist fusion Her-EX4-Lep and co-administration of Her-Lep with Her-EX4-Lep ${ }^{\mathrm{M}}$ outperformed the mono leptin antibody fusion Her-Lep with respect to body weight reduction $(33.75 \pm 3.74 \%$ decrease for Her-EX4-Lep and $32.35 \pm 2.64 \%$ decrease for Her-Lep/Her-EX4-Lep ${ }^{\mathrm{M}}$ vs a $24.5 \pm 3.69 \%$ decrease for Her-Lep; all decreases are relative to body weight at day 0), indicating the increased effect of GLP-1R and ObR co-agonism. For comparison, the body weights of mice treated with antibody fusions with only GLP-1R agonistic activity (Her-EX4 and Her-EX4Lep $^{\mathrm{M}}$ ) decreased only modestly (up to $5.5 \pm 1.0 \%$ and $3.7 \pm 1.1 \%$, respectively) after the first two injections and then gradually increased through the remainder of the treatment period. Consistent with the body weight losses, the groups treated with Her-Lep, Her-EX4Lep, and Her-Lep/Her-EX4-Lep ${ }^{\mathrm{M}}$ exhibited improved glucose tolerance compared to both the vehicle group and Her-EX4 (Figure S3a). Moreover, treatment with Her-EX4 and HerEX4-Lep ${ }^{\mathrm{M}}$ had no effect on fat mass $(50.93 \pm 4.36 \%$ and $50.61 \pm 2.26 \%$ versus 53.06 $\pm 2.05 \%$ for saline treatment), while treatment with the ObR agonist antibodies showed a significant reduction in fat mass: Her-Lep $(45.44 \pm 3.3 \%$, p $<0.01)$ and Her-EX4-Lep (45.55 
$\pm 5 \%, \mathrm{p}<0.01$ ) (Figure S3b). Correspondingly, treatment with Her-Lep, Her-EX4-Lep, and the combination of Her-Lep and Her-EX4-Lep ${ }^{\mathrm{M}}$ significantly increased the percentage of lean mass; Her-EX4 and Her-EX4-Lep ${ }^{\mathrm{M}}$ had no significant effects (Figure S3c).

Next, the in vivo efficacy of the dual agonist fusion Her-EX4-Lep was determined in dietinduced obesity (DIO) mice. Previous studies have indicated that pre-treatment with EX4 suppresses food intake and restores endogenous leptin responsiveness, "sensitizing" mice to exogenous leptin ${ }^{2,29}$. Therefore, Her-EX4 was initially dosed at $2 \mathrm{mg} / \mathrm{kg}$ subcutaneously twice in all treatment groups (at day -4 and -2), followed by subcutaneous administration of Her-EX4-Lep, Her-EX4-Lep ${ }^{\mathrm{M}}$, Her-Lep, and co-administration of Her-Lep and Her-EX4$\mathrm{Lep}^{\mathrm{M}}$ at $5 \mathrm{mg} / \mathrm{kg}$. The high fat diet (HFD) was maintained throughout the entire treatment period and daily body weights are shown in Figure S4-a. Upon initial dosing of Her-EX4 at Day -4 , the body weights of DIO mice decreased 6 10\% in the 4 days prior to dosing of the antibody fusion proteins, likely due to the suppression of food intake by EX4. After day 0, Her-Lep treatment did not show any significant effect on body weight loss (likely due to "leptin resistance" in the absence of GLP-1R co-activation). Her-EX4-Lep, Her-EX4-Lep ${ }^{\mathrm{M}}$, and Her-Lep/Her-EX4-Lep ${ }^{\mathrm{M}}$ treatment showed similar effects on body weight loss (8\%) relative to the vehicle group (Figure $3 \mathrm{~b}$ ). These three groups also exhibited improved glucose tolerance compared to both saline and Her-Lep treatment (Figure S4b). The lack of significant differences in body weight loss among these three groups in this acute dosing paradigm is similar to previous observations that co-administration of PEG-Leptin with EX4 or FGF21 fails to restore leptin responsiveness when a HFD is maintained during treatment ${ }^{29}$, and supports the argument that the HFD is a key factor causing leptin resistance ${ }^{2}$. Nevertheless, it is worth noting that the dual agonist Her-Ex4-Lep did exhibit a significant loss in fat mass compared to the vehicle group (weight: $10.95 \pm 3.62 \mathrm{~g}$ versus $15.26 \pm 3.61 \mathrm{~g}$; fat mass percentage: $30.4 \pm 7.9 \%$ versus $38.3 \pm 8.7 \%, \mathrm{p}<0.05$ ) in this model (Figure 3c). This latter observation suggests that GLP-1R agonism does to some degree potentiate the effect of leptin on fat mass in the DIO model even under continuous HFD conditions. We suspect that it may take longer treatments with Her-EX4-Lep to have more pronounced effects on body weight, but such regimens require a mouse surrogate antibody scaffold to avoid the immunogenicity induced by our human antibody sequence. Alternatively, more closely matching of the half-lives of the two hormones could further increase efficacy. Finally, in vivo studies in non-human primates are important to assess the effects of EX4/Leptin dual agonists due to large metabolic differences between rodents and higher species.

In summary, we have demonstrated that dual agonist antibody fusions can be generated by fusion of GLP-1 and leptin to the N-terminus of the heavy chain and CDR3 loop of the light chain of Herceptin, respectively. These dual antibody fusion proteins retain the in vitro potency of the parent polypeptides on GLP-1R and ObR, but have significantly extended circulating half-lives in rodents. In comparison to the antibody fusion of either EX4 or leptin alone, the leptin/EX4 dual antibody fusion leads to a greater reduction in body weight in $o b / o b$ mice and reduced fat mass in $D I O$ mice under continuous HFD. A similar antibody fusion approach should allow the generation of other multi-functional fusion antibodies, although in each case the half-lives of the individual fusion polypeptides may have to be modulated. 


\section{EXPERIMENTAL PROCEDURES}

Full details for all experimental methods are provided in the Supporting Information.

\section{Supplementary Material}

Refer to Web version on PubMed Central for supplementary material.

\section{References}

1. Zhang Y, Proenca R, Maffei M, Barone M, Leopold L, Friedman JM. Positional cloning of the mouse obese gene and its human homologue. Nature. 1994; 372:425-432. [PubMed: 7984236]

2. Clemmensen C, Chabenne J, Finan B, Sullivan L, Fischer K, Kuchler D, Sehrer L, Ograjsek T, Hofmann SM, Schriever SC, Pfluger PT, Pinkstaff J, Tschop MH, Dimarchi R, Muller TD. GLP-1/ glucagon coagonism restores leptin responsiveness in obese mice chronically maintained on an obesogenic diet. Diabetes. 2014; 63:1422-1427. [PubMed: 24379349]

3. Roujeau C, Jockers R, Dam J. New pharmacological perspectives for the leptin receptor in the treatment of obesity. Front Endocrinol (Lausanne). 2014; 5:167. [PubMed: 25352831]

4. Coppari R, Bjorbaek C. Leptin revisited: its mechanism of action and potential for treating diabetes. Nat Rev Drug Discov. 2012; 11:692-708. [PubMed: 22935803]

5. Morton GJ, Gelling RW, Niswender KD, Morrison CD, Rhodes CJ, Schwartz MW. Leptin regulates insulin sensitivity via phosphatidylinositol-3-OH kinase signaling in mediobasal hypothalamic neurons. Cell Metab. 2005; 2:411-420. [PubMed: 16330326]

6. Rodgers RJ, Tschop MH, Wilding JP. Anti-obesity drugs: past, present and future. Dis Model Mech. 2012; 5:621-626. [PubMed: 22915024]

7. Sadry SA, Drucker DJ. Emerging combinatorial hormone therapies for the treatment of obesity and T2DM. Nat Rev Endocrinol. 2013; 9:425-433. [PubMed: 23478327]

8. Farooqi IS, Matarese G, Lord GM, Keogh JM, Lawrence E, Agwu C, Sanna V, Jebb SA, Perna F, Fontana S, Lechler RI, DePaoli AM, O’Rahilly S. Beneficial effects of leptin on obesity, T cell hyporesponsiveness, and neuroendocrine/metabolic dysfunction of human congenital leptin deficiency. J Clin Invest. 2002; 110:1093-1103. [PubMed: 12393845]

9. Licinio J, Caglayan S, Ozata M, Yildiz BO, de Miranda PB, O’Kirwan F, Whitby R, Liang L, Cohen P, Bhasin S, Krauss RM, Veldhuis JD, Wagner AJ, DePaoli AM, McCann SM, Wong ML. Phenotypic effects of leptin replacement on morbid obesity, diabetes mellitus, hypogonadism, and behavior in leptin-deficient adults. Proc Natl Acad Sci U S A. 2004; 101:4531-4536. [PubMed: 15070752]

10. Halaas JL, Gajiwala KS, Maffei M, Cohen SL, Chait BT, Rabinowitz D, Lallone RL, Burley SK, Friedman JM. Weight-reducing effects of the plasma protein encoded by the obese gene. Science. 1995; 269:543-546. [PubMed: 7624777]

11. Halaas JL, Boozer C, Blair-West J, Fidahusein N, Denton DA, Friedman JM. Physiological response to long-term peripheral and central leptin infusion in lean and obese mice. Proc Natl Acad Sci U S A. 1997; 94:8878-8883. [PubMed: 9238071]

12. Lin S, Thomas TC, Storlien LH, Huang XF. Development of high fat diet-induced obesity and leptin resistance in C57B1/6J mice. Int J Obes Relat Metab Disord. 2000; 24:639-646. [PubMed: 10849588]

13. Van Heek M, Compton DS, France CF, Tedesco RP, Fawzi AB, Graziano MP, Sybertz EJ, Strader CD, Davis HR Jr. Diet-induced obese mice develop peripheral, but not central, resistance to leptin. J Clin Invest. 1997; 99:385-390. [PubMed: 9022070]

14. Scarpace PJ, Zhang Y. Leptin resistance: a prediposing factor for diet-induced obesity. Am J Physiol Regul Integr Comp Physiol. 2009; 296:R493-500. [PubMed: 19091915]

15. Liu T, Zhang Y, Liu Y, Wang Y, Jia H, Kang M, Luo X, Caballero D, Gonzalez J, Sherwood L, Nunez V, Wang D, Woods A, Schultz PG, Wang F. Functional human antibody CDR fusions as 
long-acting therapeutic endocrine agonists. Proc Natl Acad Sci U S A. 2015; 112:1356-1361. [PubMed: 25605877]

16. Zhang Y, Liu Y, Wang Y, Schultz PG, Wang F. Rational design of humanized dual-agonist antibodies. J Am Chem Soc. 2015; 137:38-41. [PubMed: 25494484]

17. Zhang Y, Zou H, Wang Y, Caballero D, Gonzalez J, Chao E, Welzel G, Shen W, Wang D, Schultz PG, Wang F. Rational design of a humanized glucagon-like peptide-1 receptor agonist antibody. Angew Chem Int Ed Engl. 2015; 54:2126-2130. [PubMed: 25556336]

18. Baselga J, Tripathy D, Mendelsohn J, Baughman S, Benz CC, Dantis L, Sklarin NT, Seidman AD, Hudis CA, Moore J, Rosen PP, Twaddell T, Henderson IC, Norton L. Phase II study of weekly intravenous trastuzumab (Herceptin) in patients with HER2/neu-overexpressing metastatic breast cancer. Semin Oncol. 1999; 26:78-83.

19. Goldenberg MM. Trastuzumab, a recombinant DNA-derived humanized monoclonal antibody, a novel agent for the treatment of metastatic breast cancer. Clin Ther. 1999; 21:309-318. [PubMed: 10211534]

20. Cho HS, Mason K, Ramyar KX, Stanley AM, Gabelli SB, Denney DW Jr, Leahy DJ. Structure of the extracellular region of HER2 alone and in complex with the Herceptin Fab. Nature. 2003; 421:756-760. [PubMed: 12610629]

21. Shak S. Overview of the trastuzumab (Herceptin) anti-HER2 monoclonal antibody clinical program in HER2-overexpressing metastatic breast cancer. Herceptin Multinational Investigator Study Group. Semin Oncol. 1999; 26:71-77. [PubMed: 10482196]

22. Armour KL, Clark MR, Hadley AG, Williamson LM. Recombinant human IgG molecules lacking Fcgamma receptor I binding and monocyte triggering activities. Eur J Immunol. 1999; 29:26132624. [PubMed: 10458776]

23. Shields RL, Namenuk AK, Hong K, Meng YG, Rae J, Briggs J, Xie D, Lai J, Stadlen A, Li B, Fox JA, Presta LG. High resolution mapping of the binding site on human IgG1 for Fc gamma RI, Fc gamma RII, Fc gamma RIII, and FcRn and design of IgG1 variants with improved binding to the Fc gamma R. J Biol Chem. 2001; 276:6591-6604. [PubMed: 11096108]

24. Niv-Spector L, Shpilman M, Grupi A, Gertler A. The obese phenotype-inducing N82K mutation in human leptin disrupts receptor-binding and biological activity. Mol Genet Metab. 2010; 100:193197. [PubMed: 20307995]

25. Parkes D, Jodka C, Smith P, Nayak S, Rinehart L, Gingerich R, Chen K, Young A. Pharmacokinetic actions of exendin-4 in the rat: Comparison with glucagon-like peptide-1. Drug Development Research. 2001; 53:260-267.

26. Gao W, Jusko WJ. Target-mediated pharmacokinetic and pharmacodynamic model of exendin-4 in rats, monkeys, and humans. Drug Metab Dispos. 2012; 40:990-997. [PubMed: 22338110]

27. Vila R, Adan C, Rafecas I, Fernandez-Lopez JA, Remesar X, Alemany M. Plasma leptin turnover rates in lean and obese Zucker rats. Endocrinology. 1998; 139:4466-4469. [PubMed: 9794453]

28. Hill RA, Margetic S, Pegg GG, Gazzola C. Leptin: its pharmacokinetics and tissue distribution. Int J Obes Relat Metab Disord. 1998; 22:765-770. [PubMed: 9725636]

29. Muller TD, Sullivan LM, Habegger K, Yi CX, Kabra D, Grant E, Ottaway N, Krishna R, Holland J, Hembree J, Perez-Tilve D, Pfluger PT, DeGuzman MJ, Siladi ME, Kraynov VS, Axelrod DW, DiMarchi R, Pinkstaff JK, Tschop MH. Restoration of leptin responsiveness in diet-induced obese mice using an optimized leptin analog in combination with exendin-4 or FGF21. J Pept Sci. 2012; 18:383-393. [PubMed: 22565812] 


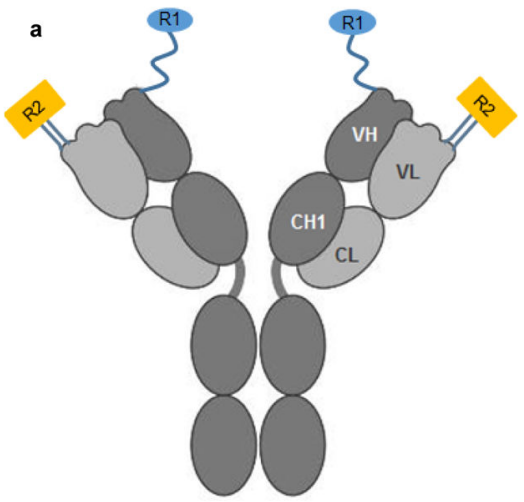

b

\begin{tabular}{lcc}
$\begin{array}{c}\text { Antibody } \\
\text { Scaffold }\end{array}$ & R1 & $\mathbf{R 2}$ \\
\hline & EX4 & - \\
Herceptin & - & $\begin{array}{l}\text { Leptin } \\
\text { Leptin }\end{array}$ \\
\hline
\end{tabular}

Figure 1.

Design of dual agonist antibodies based on Herceptin scaffold by fusion of EX4 and Leptin at the N-terminus of the heavy chain (via a flexible linker) and in the CDR3 loop of the light chain (via a rigid coiled-coil linker), respectively. All of the antibody fusion proteins were produced as full-length IgGs. The fused moieties are listed in (b). 


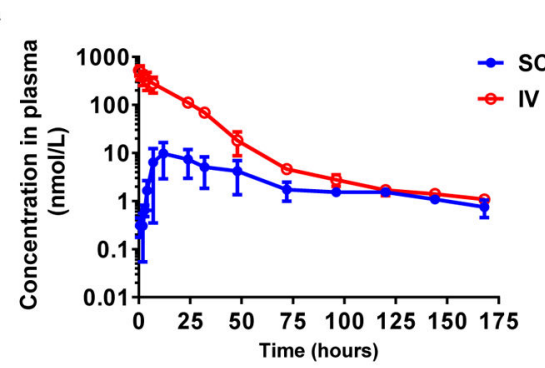

b

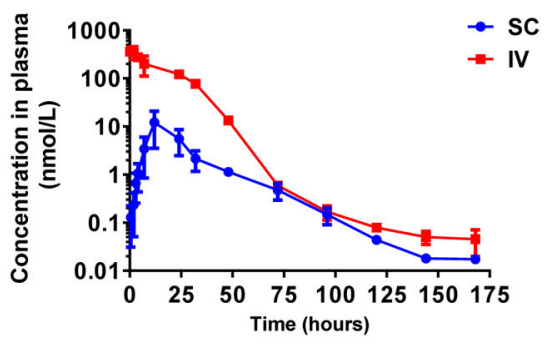

Figure 2.

Pharmacokinetics of Her-EX4-Lep in SD rats. A single dose of Her-EX4-Lep at $2 \mathrm{mg} / \mathrm{kg}$ in PBS (pH 7.4) was administered by intravenous (i.v.) or subcutaneous (s.c.) injection into SD female rats $(n=3)$. Blood samples were collected at the indicated time points and analyzed by a sandwich ELISA using an anti-human Fc antibody and an EX4 or leptin-specific antibody. (a) Concentration of Her-EX4-Lep in plasma based on detection of anti-human Fc and antiEX4. (b) Concentration of Her-EX4-Lep in plasma based on detection of anti-human Fc and anti-leptin. Data was analyzed by WinNonlin using a two-compartment model. 
a

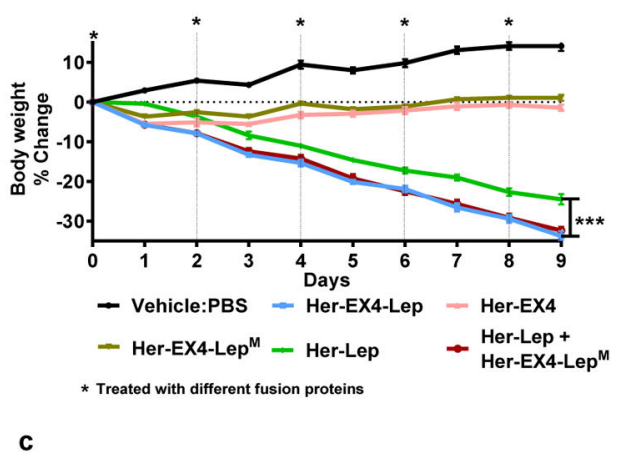

c

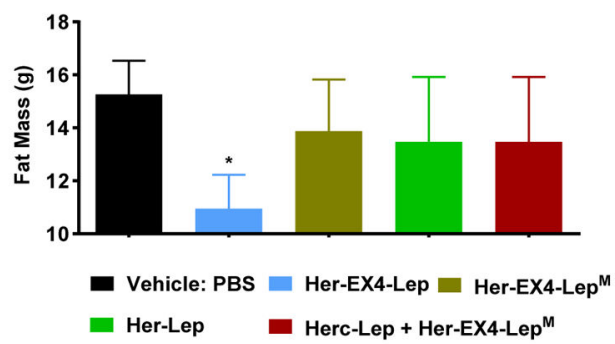

b

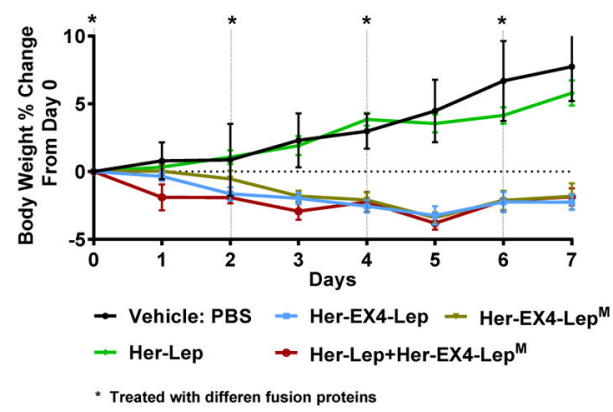

Figure 3.

In vivo efficacy of the antibody fusion proteins. (a) in $o b / o b$ mice: Her-EX4, Her-Lep, HerEX4-Lep, Her-EX4-Lep ${ }^{M}$, and co-administration of Her-EX4 and Her-EX4-Lep ${ }^{M}$ at $5 \mathrm{mg} / \mathrm{kg}$ subcutaneously every other day for 5 injections during 10 days. Body weight changes were monitored daily. The asterisks indicate the treatment of different fusion proteins at day 0,2 , 4, 6, and 8; ***, p<0.001; (b\&c) in DIO mice: Initially Her-EX4 was subcutaneously injected at $2 \mathrm{mg} / \mathrm{kg}$ every other day for 2 injections in DIO mice, then the mice were divided into treatment groups of Her-Lep, Her-EX4-Lep, Her-EX4-Lep ${ }^{\mathrm{M}}$, and the combination of Her-EX4 and Her-EX4-Lep ${ }^{\mathrm{M}}$ and dosed at $5 \mathrm{mg} / \mathrm{kg}$ subcutaneously every other day for 4 injections. (b) Daily body weight changes are shown after Day 0; Asterisks indicate the treatment of different fusion proteins at day 0,2, 4 and 6; (c) fat mass comparison; asterisks indicate significant differences relative to the vehicle group; $*, p<0.05$; Values represent means \pm standard error of the mean. 


\section{Table 1}

In vitro activities of the antibody fusions. $\mathrm{EC}_{50}$ values for activation of GLP-1R and leptin dependent proliferation. The yields $(\mathrm{mg} / \mathrm{L})$ of the fusion antibodies are based on purified material after expression from FreeStyle 293-F cells by transient transfection.

\begin{tabular}{|l|c|c|c|}
\hline Protein & EC50 GLP-R (pM) & EC50 proliferation $(\mathbf{p M})$ & Yield (mg/L) \\
\hline Her-EX4 & $3.4 \pm 1.0$ & - & 32 \\
\hline Her-Lep & - & $70.1 \pm 3.8$ & 6 \\
\hline Her-EX4-Lep & $20.5 \pm 1.6$ & $91.2 \pm 5.0$ & 18 \\
\hline Her-EX4-Lep & $18.0 \pm 1.3$ & $>10^{5}$ & 18 \\
\hline EX4 & $33.6 \pm 4.2$ & - & - \\
\hline Leptin & - & $110.6 \pm 15.8$ & - \\
\hline
\end{tabular}

